\title{
ANALISA PROGRAM BOOKING SERVICE TERHADAP KEPUASAAN KONSUMEN DENGAN METODE KAIZEN DI BENGKEL AUTO 2000 PT. ASTRA INTERNATIONAL TBK JALAN SISINGAMANGARAJA NO. 8 MEDAN
}

\author{
Abdurrozzaq Hasibuan ${ }^{(1)}$ Siti Rahmah Subueah $^{(2)}$ Khoirumansyah $^{(3)}$ \\ ${ }^{(1,2)}$ Staf Pengajar (Dosen) Program Studi Teknik Industri Fakultas Teknik \\ Universitas Islam Sumatera Utara (UISU) Jalan S.M Raja Medan \\ ${ }^{(3)}$ Alumni Program Studi Teknik Industri Fakultas Teknik UISU \\ Email : rozzaq@uisu.ac.id; khoiruman_syah@yahoo.com
}

\begin{abstract}
Abstrak
PT. Astra International, Tbk merupakan perusahaan multinasional sebagai dealer kenderaan merk Toyota. Program Booking Service diterapkan untuk memenuhi harapan pelanggan terhadap pelayanan yang cepat. Penelitian ini menganalisis pengaruh Program Booking Service terhadap kepuasan Konsumen dengan menggunakan metode Analisis Korelasi dan menerapkan Metode Kaizen. Berdasarkan penelitian disimpulkan bahwa hubungan antara Program Booking Service terhadap Kepuasan Konsumen ternyata "Rendah". Hal ini dibuktikan dengan Korelasi $\mathrm{r}=$ 0,265, sebab berdasarkan Tabel Nilai Hubungan Koefisien Korelasi bila r berada diantara 0,200 - 0.399 ditafsirkan hubungan antara variabel adalah masih Rendah. Kekuatan pengaruh Program Booking Service berpengaruh terhadap Kepuasan Konsumen dapat diukur dengan koefisien determinasi yaitu sebesar 7,022\% dan sisanya 92,978\% efektifitas kerja dipengaruhi variabel lain diluar penelitian ini. Maka perlu dilakukan perbaikan secara terus-menerus untuk meningkatkan pengaruh Program Booking service terhadap kepuasan Konsumen, Keluhan yang banyak dihadapi oleh konsumen adalah waktu tunggu telepon dalam Booking Service, perbaikan yang dilakukan adalah : Menambah Akses dengan Via Whatsapp dan Aplikasi Line, serta menambah jumlah operator dibagian Booking Service dengan menerapkan metode Kaizen dengan konsep PDCA (Plan Do Chek Act) dimana hakekatnya merupakan sebuah siklus, serta implementasinya akan membangun budaya mutu yang continual improvement.
\end{abstract}

Kata-Kata Kunci : Kepuasaan Konsumen, Analisis Korelasi, Metode Kaizen, PDCA.

\begin{abstract}
PT. Astra International, Tbk is a multinational company as a dealer of Toyota brand vehicles. Booking Service programs implemented to meet customer expectations for fast service. This study analyzed the effect of Booking Service Program for Consumer satisfaction with using correlation analysis method and applying Kaizen method. Based on the study concluded that the relationship between program Booking Service for Consumer Satisfaction turns "Low". This is evidenced by the correlation of $r=0.265$, because based on Table Value Relationship Correlation Coefficient if $\mathrm{r}$ is between 0.200 to 0399 interpreted the relationship between variables is still Low. Strength influence Booking Service Programs effect on customer satisfaction can be measured by the coefficient of determination is equal to $7.022 \%$ and the remaining $92.978 \%$ effectiveness of work is influenced by other variables outside of this research. It needs to be improved continuously to improve the effect of program booking service to customer satisfaction, complaints that many consumers are faced by the phone waiting time in the Booking Service, improvements made are: Increase access to Via Whatsapp and Applications Line, as well as increasing the number of operators section booking Service by applying Kaizen method with the concept PDCA (Plan Do Chek Act) which essentially is a cycle, and its implementation will build a culture of continual improvement quality.
\end{abstract}

Keywords : Customer satisfaction, Correlation Analysis, Methods Kaizen, PDCA. 


\section{PENDAHULUAN}

Seiring dengan kemajuan dan perkembangan zaman maka persaingan dalam dunia bisnis semakin ketat, hal tersebut juga dapat dirasakan di Indonesia. Kenyataan tersebut kita lihat dari banyaknya usaha pelayanan yang dilakukan oleh masing perusahaan yang ada untuk mendapatkan hasil penjualan yang setinggi-tingginya, memperoleh pelanggan baru, dan mempertahankan pelanggan yang sudah ada. Selain itu kondisi pasar juga semakin terpecah-pecah, daur usia produk semakin pendek, dan adanya perubahan perilaku konsumen membuat pemasaran semakin penting.

Dengan lingkungan persaingan yang ketat ini, konsumen memiliki peluang yang sangat luas untuk mendapatkan produk yang sesuai dengan keinginan dan kebutuhan sehingga perusahaan tidak hanya berkonsentrasi bagaimana produk sampai kepada konsumen tetapi lebih fokus mempertahankan konsumen dengan memahami keinginan dan kebutuhan konsumen dengan memberikan pelayananpelayanan terbaik serta kemudahan-kemudahan dalam melakukan service terhadap kenderaannya sebab Ekspektasi pelanggan terhadap pelayanan bengkel yang cepat masih belum terpenuhi, hal ini terbukti dari hasil survey kepuasan pelanggan terhadap waktu tunggu service yang masih rendah. Dan Waktu tunggu penerimaan service di bengkel Auto 2000 Medan Jln. Sisingamangaraja yang masih cukup lama, serta Kecenderungan pelanggan yang selalu datang di pagi hari sehingga mengakibatkan morning rush.

Maka mengupayakan pelayan yang lebih baik (Better in service), seiring dengan kian berkembangnya $e$ bussiness, memaksa perusahaan menggunakan solusi dan aplikasi untuk mempertahankan bisnisnya. Perusahaan tidak lagi hanya memikirkan keuntungan semata tetapi mulai memikirkan sektor potensial lainnya yang dapat mempertahankan dan meningkatkan pendapatan sehingga kepentingan pelanggan pun menjadi perhatian utama. Karenanya berbagai upaya dilakukan agar hubungan konsumen dengan perusahaan berjalan dengan baik.

PT. Astra International Tbk. atau yang biasa disebut dengan AUTO 2000 merupakan sebagai dealer resmi penjualan produk Toyota di Indonesia merupakan jaringan jasa penjualan, perawatan, perbaikan dan penyediaan suku cadang Toyota yang manajemennya ditangani penuh oleh PT Astra International Tbk. Saat ini AUTO 2000 adalah main dealer Toyota terbesar di Indonesia, yang menguasai antara $70-80 \%$ dari total penjualan Toyota. Dealer yang menjadi lokasi penelitian saya adalah dealer AUTO 2000 Jln.Sisingamangaraja No. 8 Medan. Pada dealer AUTO 2000 Sisingamangaraja ini selalu terjadi peningkatan penjualan setiap tahunnya, dibanding dengan dealer lain cabang AUTO2000 yang ada di Kota Medan.Maka untuk mengatasi masalah dalam pelayanan tersebut makan AUTO 2000 Sisingamangaraja Medan melakukan program booking service. Penelitian ini hanya dilakukan kepada konsumen perseorangan saja karena konsumen perseorangan lebih merasakan dampak dari service booking tersebut.

Program booking service merupakan program yang memudahkan konsumen dalam melakukan perawatan mereka, adapun manfaat dari program booking service adalah sebagai berikut:

- Sebagai suatu bentuk pelayanan untuk memenuhi harapan konsumen terhadap pelayanan yang cepat

- Supaya bisa mempersiapkan mekanik dan menghindari morning rush atau kesibukan diwaktu tertentu saja.

- Mencari ide-ide perbaikan untuk mengurangi waktu tunggu penerimaan service dan meratakan jam kedatangan pelanggan

Selain persaingan antar merek yang semakin ketat, pertambahan jumlah kompetitor menuntut AUTO 2000 untuk tetap menjadi panutan dalam memberikan pelayanan kepada konsumen. Dengan menciptakan ide-ide baru/program-program baru dalam memberikan layanan terbaik dan kemudahankemudahan kepada konsumennya termasuk memberikan pelayanan dalam bentuk program booking service. Selain itu Peneliti juga ingin mengetahui dan mempelajari mekanisme dari proses program booking service tersebut.

\section{METODOLOGI PENELITIAN}

Metodologi penelitian merupakan proses pemecahan masalah yang digunakan untuk menyelesaikan persoalan yang timbul, yang disusun berdasarkan latar belakang dan tujuan yang ingin dicapai dengan menggunakan teori-teori oendukung dalam pemecahan masalah, dan melakukan pengumpulan data baik melalui literature maupun melalui studi lapangan, melakukan pengolahan data sampai pada penarikan kesimpulan yang diteliti.

\section{Studi Pendahuluan}

Studi pendahuluan merupakan studi awal yang dilkukan dalam penyusunan Skripsi ini. Adapun studi awal yang dilakukan adalah studi di lapangan (tempat 
penelitian) dan studi pustaka. Studi lapangan merupakan, studi dimana penulis melakukan pengamatan langsung ke perusahaan dan meneliti tentang aktivitas dan mekanisme dari Booking Service yang ada di perusahaan. Sedangkan studi pustaka adalah kegiatan penulis dalam mengumpulkan serta mencari sumber dan bahan-bahan seputar program Booking Service dan pelayanan pada industri jasa serta penerapan Metode Kaizen dari berbagai buku, juga dari internet tentang jurnal pelayanan terhadap kepuasan pelanggan dan metode Kaizen.

\section{Perumusan Masalah}

Berdasarkan Latar Belakang masalah yang diuraikan maka dikemukakan perumusan masalah yaitu:

- Bagaimana pengaruh Booking Service terhadap kepuasaan konsumen

- Kendala yang dihadapi perusahaan dalam menerapkan Booking Service

- Perbaikan yang dilakukan terhadap kendala dalam program Booking Service

Sehinggan harapan pelanggan terhadap pelayanan yang cepat bisa terpenuhi.

Maka penerapan program booking service di AUTO 2000 Jln. Sisingamangaraja Medan dapat menjadi solusi dan dapat memberikan kemudahan serta meningkatkan kepuasan pelanggan terhadap pelayanan yang baik sesuai keinginan dan kebutuhan.

\section{Tujuan Penelitian}

Tujuan yang ingin dicapai dari penelitian ini adalah sebagai berikut :

Untuk mengetahui seberapa besar pengaruh Booking Service terhadap kepuasaan pelanggan, dan menemukan kendala apa saja yang dihadapi dalam menerapkan program Booking Service tersebut. Serta untuk mengetahui perbaikan yang harus dilakukan untuk menanggulangi kendala yang dihadapi. Dengan menerapkan metode Kaizen menggunakan konsep PDCA (Plan Do Chek Act) dimana hakekatnya merupakan sebuah siklus, serta implementasinya akan membangun budaya mutu yang continual improvement untuk meningkatkan pengaruh Booking Service terhadap kepuasan konsumen.

\section{Metodologi Pemecahan Masalah}

Metodologi pemecahan masalah yang digunakan untuk mengumpulkan data adalah sebagai berikut:

1. Studi lapangan yaitu dengan pengamatan langsung pada bagian Booking service dan mengamati mekanisme dari Booking service tersebut serta langsung menemui pelanggan dan melakukan wawancara dengan pegawai dan pihak-pihak yang dapat memberikan informasi yang berkaitan dengan data Booking service serta menyurvey pelanggan.
2. Studi kepustakaan merupakan penelaahan terhadap kualitas Air Bersih dan pelayanan yang berkaitan dengan kepuasan pelanggan

3. Serta mencari referensi lain seperti dari Internet materi yang berkaitan dengan judul / materi yang dibutuhkan oleh penulis.

4. Identifikasi Variabel Penelitian

Sesuai dengan tujuan penelitian, maka variabel dalam penelitian adalah sebagai berikut:

a. Variabel Bebas (X), adalah variabel yang mempengaruhi variabel terikat,

b. Variabel Terikat (Y), adalah variabel yang nilainya akan diketahui atau dicari yaitu mengenai tingkat kepuasan pelanggan

5. Penyusunan Kuisioner

Pengumpulan data dilakukan dengan menggunakan kuisioner. Kuisioner yang digunakan yaitu kuisioner tertutup dimana jawaban telah disediakan sejumlah alternative jawabannya. Sehingga jawaban yang di dapat tidak akan berkisar jauh dari alternative yang telah diberikan. Kuisioner ini terdiri dari:

- Mengenai biodata pelanggan

- Mengenai tanggapan pelanggan tentang program Booking service

- Mengenai tanggapan pelanggan tentang kepuasan pelanggan akan sistem pelayanan.

Pertanyaan-pertanyaan dalam kuisioner disusun dan dikembangkan berdasarkan variabel-variabel yang akan di ukur. Pengukuran variabel menggunakan skala likert. Dalam skala likert, respon subjek terhadap objek dibagi atas tiga kategori jawaban yang menunjukkan derajat sangat puas, puas, dan tidak puas.

Pengukuran skala likert yang digunakan adalah sebagai berikut:

- Sangat puas = nilai 3

- Puas = nilai 2

- Tidak puas = nilai 1

6. Penyebaran Kuisioner

Penyebaran kuisioner dilakukan pada tanggal 18 Nopember 2014 sampai 22 Nopember 2014 pada pelanggan PT. Astra Internasional Tbk. (AUTO 2000) Jln. Sisingamangaraja Medan dimana penetapan jumlah responden dilakukan dengan :

dimana :

$$
\mathrm{n}=\frac{\mathbb{N}}{N \cdot d^{2}+1}
$$

$\mathrm{n}=$ jumlah sampel

$\mathrm{N}=$ Jumlah polulasi $=600$ responden

$d^{2}=$ presisi (ditetapkan $10 \%$ dengan tingkat

kepercayaan 95\%)

Berdasarkan rumus tersebut diperoleh jumlah sampel sebagai berikut:

$$
\begin{aligned}
& \mathrm{n}=\frac{N}{N \cdot d^{2}+1}=\frac{600}{600 \cdot 0 \cdot 1^{2}+1}=\frac{600}{7} \\
& \mathrm{n}=85,7 \\
& \mathrm{n}=85 \text { responden. }
\end{aligned}
$$


7. Pengolaha Data

Pengumpulan data di lakukan dengan langsung mendatangi pelanggan yang dilakukan oleh Penulis dan meminta data yang bersangkutan pada pegawai di bidang Booking servie. Teknik pengumpulan data yang digunakan adalah dengan cara menyebarkan kuisioner dan hasil penyebaran kuisioner sudah kembali seluruhnya.

8. Teknik Analisa Data

Langkah-langkah pengolahan data untuk memecahkan permasalahan adalah sebagai berikut :

a. Menghitung Korelasi Product Moment

$\mathrm{r} x=\frac{\mathrm{n} \sum x y-\sum x \sum y}{\sqrt{\left\{\mathrm{n} \sum x^{2}-\left(\sum \mathrm{x}\right)^{2}\right\}\left\{\mathrm{n} \sum y^{2}-\left(\sum y\right)^{2}\right\}}}$

Keterangan :

$\mathrm{r} x y=$ Koefisien Korelasi Antara Variabel $\mathrm{x}$ dan Variabel y

$x$ = Variabel Kualitas Air Dalam Pelayanan

$y=$ Variabel Kepuasan Pelanggan

$\mathrm{n} \quad=$ Jumlah Sampel

b. Menguji Signifikansi Hubungan

Untuk menguji signifikansi hubungan rumus uji signifikansi korelasi product moment yang ditujukan pada rumus berikut:

thitung $=\frac{r \sqrt{n-2}}{\sqrt{1-r^{2}}}$

c. Menghitung Koefisien Determinasi

$$
D=r x y^{2} \times 100 \%
$$

Keterangan :

$\mathrm{D}=$ Koefisien Determinasi

rxy $=$ Koefisien Korelasi Product Moment antara $\mathrm{x}$ dan $\mathrm{y}$

9. Analisa dan Evaluasi serta memasukkan Metode Kaizen

Pada bagian ini adalah mengalisa dan mengevaluasi hubungan keterkaitan anatara variabel bebas dan variabel terikat, sehingga dapat diketahui seberapa besar pengaruhnya terhadap variabel veriabel tersebut dengan metode korelasi, Dan untuk menyelesaikan persoalan yang dihadapi pelanggan maka dimasukkan Metode Kaizen pada tahap Analisa dan Evaluasi ini.

10. Kesimpulan dan Saran

Pada bagian ini penelis menjelaskan dan mengambil suatu kesimpulan dari Penelitian yang dilakukan dan berusaha memberikan saran sesuai dengan apa yang penulis pelajari selama penelitian.

\section{Pengumpulan Data}

Dalam metode pengumpulan data, cara yang dilakukan adalah dengan melakukan wawancara, pengamatan langsung proses Booking dan mengumpulkan data yang berasal dari dokumentasi perusahaan. Serta melakukan wawancara dan menyebarkan kuesioner kepada pelanggan seputar program Booking Service sehingga penulis mendapat permasalahan yang sering dihadapi pelanggan dalam melakukan proses Booking Service.

Pengumpulan data dilakukan di PT. Astra Internasional Tbk, adapun yang menjadi objek penelitian yaitu para pelanggan yang memakai jasa program Booking service. Pada saat penelitian dilakukan, berdasarkan data yang diperoleh dari bagian Maintenance Remainder System (MRS) yang merupakan pegawai dari bagian Booking service menyebutkan dalam sehari pelanggan yang melakukan Booking service yang dihubungi melalui MRS diundang untuk melakukan service berdasarkan data dari 6 bulan yang lalu adalah sebanyak rata-rata 20 pelanggan per hari dalam sebulan sekitar 600 pelanggan, jumlah itu diluar jumlah pelanggan yang melakukan Booking service secara registrasi langsung ke bagian Booking service.

Pada penelitian ini, kuisioner disebarkan pada 85 pelanggan dimana dianggap telah mewakili dari semua konsumen. Dari kuisionaer yang dibagikan ternyata hasilnya telah kembali semua dan hasil jawaban dari Responden tersebut ditabulasikan sehingga akan menjadi data.

Tabel Data Jawaban Responden Terhadap Variabel X

\begin{tabular}{|c|c|c|c|c|c|c|c|c|c|}
\hline No. & Que.1 & Que.2 & Que.3 & Que.4 & Que.5 & Que.6 & Que.7 & Que.8 & Jumlah \\
\hline 1 & 1 & $\mathbf{3}$ & 2 & 3 & 2 & 2 & 2 & 2 & 15 \\
\hline 2 & 2 & 3 & 2 & 3 & 3 & 2 & 2 & 2 & 17 \\
\hline 3 & 2 & 3 & 2 & 2 & 3 & 2 & 3 & 3 & 20 \\
\hline 4 & 2 & 3 & 3 & 3 & 3 & 2 & 2 & 2 & 20 \\
\hline 5 & 2 & 3 & 2 & 2 & 2 & 2 & 2 & 2 & 17 \\
\hline 6 & 2 & 3 & 2 & 2 & 2 & 2 & 2 & 3 & 18 \\
\hline 7 & 2 & 3 & 2 & 2 & 2 & 2 & 2 & 2 & 17 \\
\hline 8 & 2 & 3 & 2 & 2 & 3 & 2 & 2 & 3 & 19 \\
\hline 9 & 1 & 2 & 2 & 2 & 2 & 1 & 2 & 3 & 15 \\
\hline
\end{tabular}




\begin{tabular}{|c|c|c|c|c|c|c|c|c|c|}
\hline 10 & 2 & 3 & 2 & 2 & 3 & 2 & 3 & 3 & 20 \\
\hline 11 & 2 & 3 & 2 & 2 & 2 & 2 & 2 & 2 & 17 \\
\hline 12 & 2 & 3 & 2 & 2 & 1 & 2 & 2 & 2 & 16 \\
\hline 13 & 3 & 3 & 2 & 2 & 3 & 3 & 3 & 2 & 21 \\
\hline 14 & 2 & 3 & 2 & 2 & 2 & 3 & 2 & 2 & 18 \\
\hline 15 & 2 & 3 & 2 & 2 & 3 & 2 & 2 & 3 & 19 \\
\hline 16 & 1 & 3 & 2 & 2 & 3 & 2 & 2 & 3 & 18 \\
\hline 17 & 1 & 3 & 3 & 3 & 3 & 2 & 3 & 3 & 21 \\
\hline 18 & 1 & 2 & 2 & 3 & 3 & 2 & 3 & 2 & 18 \\
\hline 19 & 1 & 3 & 3 & 2 & 3 & 2 & 2 & 3 & 19 \\
\hline 20 & 2 & 3 & 2 & 2 & 2 & 2 & 2 & 3 & 18 \\
\hline 21 & 2 & 3 & 3 & 2 & 3 & 2 & 2 & 3 & 20 \\
\hline 22 & 2 & 3 & 2 & 2 & 2 & 3 & 2 & 3 & 19 \\
\hline 23 & 2 & 3 & 3 & 3 & 2 & 3 & 2 & 2 & 20 \\
\hline 24 & 2 & 3 & 2 & 2 & 2 & 3 & 2 & 3 & 19 \\
\hline 25 & 2 & 3 & 2 & 2 & 2 & 3 & 2 & 3 & 19 \\
\hline 26 & 2 & 2 & 2 & 2 & 2 & 3 & 3 & 3 & 19 \\
\hline 27 & 2 & 2 & 2 & 2 & 2 & 1 & 2 & 2 & 15 \\
\hline 28 & 2 & 3 & 2 & 2 & 3 & 2 & 2 & 3 & 19 \\
\hline 29 & 2 & 3 & 3 & 2 & 2 & 2 & 2 & 3 & 19 \\
\hline 30 & 2 & 2 & 2 & 2 & 1 & 2 & 2 & 3 & 16 \\
\hline 31 & 2 & 3 & 2 & 2 & 1 & 2 & 2 & 2 & 16 \\
\hline 32 & 2 & 3 & 2 & 2 & 3 & 2 & 3 & 3 & 20 \\
\hline 33 & 2 & 2 & 2 & 2 & 1 & 2 & 2 & 1 & 14 \\
\hline 34 & 2 & 2 & 2 & 2 & 1 & 2 & 2 & 2 & 15 \\
\hline 35 & 2 & 3 & 2 & 2 & 1 & 2 & 2 & 2 & 16 \\
\hline 36 & 1 & 2 & 2 & 3 & 2 & 1 & 2 & 2 & 15 \\
\hline 37 & 2 & 3 & 3 & 2 & 2 & 2 & 3 & 2 & 19 \\
\hline 38 & 2 & 3 & 2 & 2 & 2 & 3 & 2 & 2 & 18 \\
\hline 39 & 3 & 3 & 2 & 2 & 2 & 3 & 2 & 2 & 19 \\
\hline 40 & 1 & 3 & 2 & 2 & 2 & 3 & 2 & 2 & 17 \\
\hline 41 & 1 & 2 & 2 & 1 & 1 & 2 & 2 & 2 & 13 \\
\hline 42 & 1 & 2 & 2 & 2 & 2 & 2 & 2 & 2 & 15 \\
\hline 43 & 1 & 2 & 2 & 1 & 1 & 1 & 2 & 1 & 11 \\
\hline 44 & 2 & 3 & 3 & 2 & 3 & 2 & 2 & 2 & 19 \\
\hline 45 & 2 & 3 & 3 & 2 & 2 & 2 & 2 & 2 & 18 \\
\hline 46 & 2 & 3 & 2 & 3 & 3 & 3 & 3 & 2 & 21 \\
\hline 47 & 2 & 3 & 2 & 3 & 2 & 3 & 3 & 2 & 20 \\
\hline 48 & 2 & 3 & 3 & 2 & 2 & 2 & 2 & 2 & 18 \\
\hline 49 & 1 & 2 & 2 & 2 & 2 & 2 & 2 & 2 & 15 \\
\hline 50 & 2 & 3 & 1 & 2 & 3 & 2 & 3 & 2 & 18 \\
\hline 51 & 2 & 3 & 2 & 2 & 1 & 3 & 2 & 3 & 18 \\
\hline 52 & 2 & 2 & 2 & 2 & 3 & 2 & 3 & 2 & 18 \\
\hline 53 & 1 & 3 & 2 & 3 & 3 & 3 & 3 & 2 & 20 \\
\hline
\end{tabular}




\begin{tabular}{|c|c|c|c|c|c|c|c|c|c|}
\hline 54 & 2 & 2 & 2 & 3 & 3 & 2 & 3 & 2 & 19 \\
\hline 55 & 3 & 3 & 2 & 3 & 3 & 3 & 3 & 2 & 22 \\
\hline 56 & 3 & 3 & 2 & 2 & 3 & 3 & 2 & 2 & 20 \\
\hline 57 & 2 & 2 & 2 & 2 & 3 & 3 & 3 & 2 & 17 \\
\hline 58 & 2 & 3 & 2 & 3 & 3 & 2 & 2 & 3 & 20 \\
\hline 59 & 2 & 3 & 2 & 2 & 3 & 2 & 3 & 3 & 20 \\
\hline 60 & 2 & 3 & 2 & 2 & 3 & 3 & 2 & 2 & 19 \\
\hline 61 & 3 & 2 & 3 & 2 & 3 & 2 & 3 & 2 & 20 \\
\hline 62 & 2 & 2 & 2 & 3 & 1 & 3 & 2 & 3 & 18 \\
\hline 63 & 1 & 3 & 2 & 3 & 2 & 2 & 2 & 3 & 17 \\
\hline 64 & 2 & 3 & 2 & 3 & 3 & 2 & 2 & 2 & 19 \\
\hline 65 & 2 & 3 & 2 & 3 & 3 & 2 & 3 & 2 & 20 \\
\hline 66 & 2 & 3 & 2 & 2 & 3 & 2 & 3 & 2 & 19 \\
\hline 67 & 2 & 3 & 3 & 2 & 2 & 3 & 2 & 2 & 19 \\
\hline 68 & 2 & 3 & 2 & 2 & 2 & 2 & 2 & 3 & 18 \\
\hline 69 & 2 & 3 & 2 & 3 & 2 & 3 & 2 & 3 & 20 \\
\hline 70 & 2 & 3 & 2 & 2 & 2 & 3 & 2 & 2 & 18 \\
\hline 71 & 2 & 3 & 3 & 3 & 3 & 3 & 3 & 2 & 22 \\
\hline 72 & 2 & 3 & 3 & 2 & 3 & 3 & 3 & 2 & 21 \\
\hline 73 & 2 & 2 & 2 & 3 & 2 & 3 & 3 & 2 & 19 \\
\hline 74 & 2 & 3 & 3 & 2 & 3 & 2 & 3 & 2 & 20 \\
\hline 75 & 2 & 2 & 2 & 2 & 3 & 3 & 3 & 3 & 20 \\
\hline 76 & 2 & 2 & 2 & 2 & 3 & 2 & 2 & 3 & 18 \\
\hline 77 & 2 & 2 & 2 & 1 & 2 & 2 & 1 & 3 & 15 \\
\hline 78 & 2 & 1 & 2 & 1 & 2 & 3 & 1 & 2 & 14 \\
\hline 79 & 2 & 2 & 2 & 1 & 1 & 2 & 2 & 1 & 13 \\
\hline 80 & 2 & 3 & 2 & 2 & 3 & 2 & 1 & 2 & 17 \\
\hline 81 & 2 & 3 & 2 & 2 & 2 & 3 & 3 & 3 & 20 \\
\hline 82 & 2 & 3 & 3 & 2 & 3 & 2 & 3 & 3 & 21 \\
\hline 83 & 2 & 3 & 2 & 3 & 2 & 3 & 3 & 3 & 21 \\
\hline 84 & 2 & 3 & 3 & 1 & 3 & 3 & 2 & 3 & 20 \\
\hline 85 & 2 & 3 & 2 & 2 & 3 & 3 & 3 & 1 & 19 \\
\hline \multicolumn{9}{|c|}{ TOTAL } & 1544 \\
\hline
\end{tabular}

Tabel Data Jawaban Responden Terhadap Variabel Y

\begin{tabular}{|c|c|c|c|c|c|c|c|c|c|}
\hline No. & Que.1 & Que.2 & Que.3 & Que.4 & Que.5 & Que.6 & Que.7 & Que.8 & Jumlah \\
\hline $\mathbf{1}$ & $\mathbf{2}$ & $\mathbf{3}$ & $\mathbf{3}$ & $\mathbf{2}$ & $\mathbf{2}$ & $\mathbf{3}$ & $\mathbf{3}$ & $\mathbf{3}$ & $\mathbf{2 1}$ \\
\hline $\mathbf{2}$ & $\mathbf{2}$ & $\mathbf{3}$ & $\mathbf{3}$ & $\mathbf{2}$ & $\mathbf{2}$ & $\mathbf{3}$ & $\mathbf{3}$ & $\mathbf{3}$ & $\mathbf{2 1}$ \\
\hline $\mathbf{3}$ & $\mathbf{3}$ & $\mathbf{3}$ & $\mathbf{3}$ & $\mathbf{2}$ & $\mathbf{3}$ & $\mathbf{3}$ & $\mathbf{3}$ & $\mathbf{3}$ & $\mathbf{2 3}$ \\
\hline $\mathbf{4}$ & $\mathbf{2}$ & $\mathbf{3}$ & $\mathbf{3}$ & $\mathbf{2}$ & $\mathbf{3}$ & $\mathbf{3}$ & $\mathbf{3}$ & $\mathbf{3}$ & $\mathbf{2 2}$ \\
\hline $\mathbf{5}$ & $\mathbf{2}$ & $\mathbf{3}$ & $\mathbf{3}$ & $\mathbf{2}$ & $\mathbf{2}$ & $\mathbf{3}$ & $\mathbf{3}$ & $\mathbf{3}$ & $\mathbf{2 1}$ \\
\hline $\mathbf{6}$ & $\mathbf{2}$ & $\mathbf{3}$ & $\mathbf{3}$ & $\mathbf{2}$ & $\mathbf{2}$ & $\mathbf{3}$ & $\mathbf{3}$ & $\mathbf{3}$ & $\mathbf{2 1}$ \\
\hline $\mathbf{7}$ & $\mathbf{2}$ & $\mathbf{3}$ & $\mathbf{3}$ & $\mathbf{2}$ & $\mathbf{2}$ & $\mathbf{3}$ & $\mathbf{3}$ & $\mathbf{3}$ & $\mathbf{2 1}$ \\
\hline
\end{tabular}




\begin{tabular}{|c|c|c|c|c|c|c|c|c|c|}
\hline 8 & 2 & 3 & 3 & 2 & 2 & 3 & 3 & 3 & 21 \\
\hline 9 & 2 & 3 & 3 & 2 & 2 & 3 & 3 & 3 & 21 \\
\hline 10 & 1 & 2 & 3 & 1 & 2 & 3 & 3 & 3 & 18 \\
\hline 11 & 2 & 2 & 3 & 2 & 2 & 2 & 3 & 3 & 19 \\
\hline 12 & 3 & 3 & 3 & 3 & 2 & 3 & 3 & 3 & 23 \\
\hline 13 & 3 & 3 & 2 & 3 & 2 & 3 & 2 & 3 & 21 \\
\hline 14 & 2 & 3 & 3 & 2 & 2 & 3 & 3 & 3 & 21 \\
\hline 15 & 2 & 3 & 3 & 2 & 2 & 3 & 3 & 3 & 21 \\
\hline 16 & 2 & 3 & 3 & 2 & 2 & 2 & 3 & 3 & 20 \\
\hline 17 & 3 & 3 & 3 & 3 & 3 & 3 & 3 & 3 & 24 \\
\hline 18 & 3 & 3 & 3 & 3 & 2 & 3 & 3 & 3 & 23 \\
\hline 19 & 2 & 3 & 3 & 2 & 3 & 3 & 3 & 3 & 22 \\
\hline 20 & 2 & 3 & 3 & 2 & 2 & 3 & 3 & 3 & 21 \\
\hline 21 & 2 & 3 & 3 & 2 & 3 & 2 & 3 & 3 & 21 \\
\hline 22 & 3 & 3 & 3 & 2 & 2 & 3 & 3 & 3 & 22 \\
\hline 23 & 2 & 3 & 2 & 2 & 3 & 3 & 3 & 3 & 21 \\
\hline 24 & 2 & 3 & 2 & 2 & 2 & 3 & 3 & 3 & 20 \\
\hline 25 & 3 & 3 & 3 & 2 & 2 & 3 & 3 & 3 & 22 \\
\hline 26 & 2 & 3 & 3 & 2 & 2 & 3 & 3 & 3 & 21 \\
\hline 27 & 2 & 3 & 3 & 2 & 2 & 3 & 2 & 3 & 20 \\
\hline 28 & 2 & 3 & 3 & 2 & 2 & 3 & 3 & 3 & 21 \\
\hline 29 & 2 & 3 & 3 & 1 & 3 & 3 & 3 & 3 & 21 \\
\hline 30 & 2 & 2 & 2 & 2 & 2 & 3 & 3 & 3 & 19 \\
\hline 31 & 2 & 3 & 3 & 3 & 2 & 2 & 3 & 3 & 21 \\
\hline 32 & 2 & 3 & 3 & 3 & 2 & 3 & 3 & 3 & 22 \\
\hline 33 & 2 & 2 & 2 & 2 & 2 & 2 & 2 & 2 & 16 \\
\hline 34 & 2 & 2 & 2 & 2 & 2 & 2 & 3 & 2 & 17 \\
\hline 35 & 2 & 1 & 2 & 2 & 2 & 3 & 1 & 2 & 15 \\
\hline 36 & 2 & 2 & 2 & 3 & 2 & 2 & 2 & 1 & 16 \\
\hline 37 & 2 & 3 & 3 & 3 & 3 & 3 & 3 & 2 & 22 \\
\hline 38 & 2 & 3 & 2 & 2 & 2 & 3 & 3 & 3 & 20 \\
\hline 39 & 2 & 3 & 3 & 2 & 2 & 2 & 3 & 3 & 20 \\
\hline 40 & 2 & 3 & 2 & 3 & 2 & 2 & 3 & 3 & 20 \\
\hline 41 & 1 & 2 & 2 & 2 & 2 & 3 & 2 & 3 & 17 \\
\hline 42 & 2 & 2 & 2 & 2 & 2 & 2 & 2 & 3 & 17 \\
\hline 43 & 2 & 2 & 1 & 2 & 2 & 2 & 2 & 2 & 15 \\
\hline 44 & 3 & 3 & 3 & 3 & 3 & 3 & 3 & 3 & 23 \\
\hline 45 & 3 & 3 & 3 & 3 & 3 & 3 & 3 & 3 & 24 \\
\hline 46 & 2 & 2 & 3 & 2 & 2 & 2 & 2 & 2 & 17 \\
\hline 47 & 2 & 2 & 2 & 2 & 2 & 3 & 2 & 2 & 17 \\
\hline 48 & 2 & 3 & 2 & 2 & 3 & 3 & 3 & 3 & 23 \\
\hline 49 & 3 & 2 & 3 & 3 & 2 & 3 & 3 & 3 & 22 \\
\hline 50 & 2 & 3 & 3 & 3 & 3 & 3 & 3 & 3 & 23 \\
\hline 51 & 3 & 3 & 3 & 2 & 3 & 3 & 3 & 3 & 23 \\
\hline
\end{tabular}




\begin{tabular}{|c|c|c|c|c|c|c|c|c|c|}
\hline 52 & 2 & 3 & 3 & 3 & 2 & 2 & 3 & 2 & 20 \\
\hline 53 & 3 & 2 & 3 & 3 & 2 & 2 & 2 & 2 & 19 \\
\hline 54 & 2 & 2 & 2 & 2 & 2 & 2 & 3 & 2 & 17 \\
\hline 55 & 2 & 3 & 2 & 2 & 2 & 3 & 2 & 2 & 18 \\
\hline 56 & 2 & 3 & 2 & 2 & 2 & 2 & 3 & 2 & 18 \\
\hline 57 & 2 & 3 & 3 & 3 & 2 & 3 & 3 & 3 & 22 \\
\hline 58 & 2 & 3 & 3 & 3 & 2 & 3 & 3 & 3 & 22 \\
\hline 59 & 2 & 3 & 3 & 2 & 3 & 3 & 2 & 3 & 21 \\
\hline 60 & 3 & 3 & 2 & 3 & 3 & 3 & 3 & 3 & 22 \\
\hline 61 & 3 & 3 & 3 & 3 & 3 & 3 & 3 & 3 & 24 \\
\hline 62 & 2 & 3 & 3 & 3 & 3 & 3 & 3 & 2 & 22 \\
\hline 63 & 2 & 3 & 3 & 3 & 3 & 3 & 3 & 3 & 23 \\
\hline 64 & 2 & 3 & 2 & 2 & 3 & 2 & 3 & 3 & 20 \\
\hline 65 & 2 & 3 & 3 & 3 & 3 & 3 & 3 & 3 & 23 \\
\hline 66 & 2 & 3 & 3 & 3 & 3 & 3 & 2 & 3 & 22 \\
\hline 67 & 3 & 3 & 2 & 2 & 2 & 3 & 3 & 2 & 20 \\
\hline 68 & 3 & 3 & 3 & 3 & 3 & 3 & 3 & 2 & 23 \\
\hline 69 & 2 & 3 & 3 & 3 & 3 & 2 & 3 & 3 & 22 \\
\hline 70 & 3 & 3 & 3 & 2 & 2 & 3 & 2 & 2 & 20 \\
\hline 71 & 2 & 3 & 2 & 3 & 2 & 2 & 2 & 2 & 18 \\
\hline 72 & 2 & 3 & 2 & 3 & 2 & 2 & 2 & 2 & 18 \\
\hline 73 & 2 & 3 & 2 & 2 & 2 & 2 & 2 & 2 & 17 \\
\hline 74 & 2 & 2 & 2 & 2 & 2 & 2 & 2 & 3 & 17 \\
\hline 75 & 2 & 3 & 2 & 2 & 2 & 2 & 2 & 2 & 17 \\
\hline 76 & 1 & 3 & 2 & 3 & 2 & 2 & 2 & 3 & 18 \\
\hline 77 & 2 & 3 & 3 & 3 & 2 & 2 & 2 & 2 & 19 \\
\hline 78 & 2 & 3 & 2 & 2 & 2 & 2 & 2 & 2 & 17 \\
\hline 79 & 3 & 3 & 2 & 2 & 2 & 3 & 2 & 2 & 19 \\
\hline 80 & 1 & 3 & 2 & 2 & 2 & 2 & 2 & 2 & 16 \\
\hline 81 & 2 & 3 & 3 & 2 & 3 & 3 & 2 & 2 & 20 \\
\hline 82 & 2 & 3 & 3 & 2 & 2 & 2 & 2 & 3 & 19 \\
\hline 83 & 1 & 2 & 2 & 2 & 3 & 3 & 3 & 2 & 18 \\
\hline 84 & 2 & 3 & 2 & 2 & 2 & 2 & 2 & 2 & 17 \\
\hline 85 & 3 & 3 & 2 & 2 & 3 & 3 & 3 & 2 & 21 \\
\hline \multicolumn{9}{|c|}{ TOTAL } & 1715 \\
\hline
\end{tabular}

\section{Pengolahan Data}

Di dalam analisis terhadap data berikut ini akan di bahas sejumlah data-data yang ada, untuk melihat apakah ada pengaruh program Booking service dalam meningkatkan kepuasan pelanggan, selain itu analisis data ini juga dilakukan untuk menguji kebenaran yang ada. Hasil jawaban responden tersebut akan di hitung dalam metode Statistic Product Moment untuk mencari koefisisen dari
Variabel X dan Variabel Y. Lalu dibuat skor dari hasil angket yang di jawab responden.

Setelah di hitung skor masing-masing jawaban pelanggan setiap variabel baik Variabel X Maupun Variabel Y, maka pada tahap selanjutnya akan dilakukan langkah-langkah sebagai berikut :

a. Menjumlahkan nilai Variabel X dan Variabel Y, dari hasil data perhitungan diperoleh :

- Variabel X $=1544$

- Variabel Y $=1715$ 
b. Memperkalikan nilai / skor Variabel X dengan skor Variabel $Y$ dan hasilnya dimasukkan kedalam kolom XY kemudian dijumlahkan

c. Mengkuadratkan nilai Variabel $\mathrm{X}$ dan hasilnya dicantumkan kepada kolom $\mathrm{X}^{2}$ kemudian dijumlahkan

d. Mengkuadratkan nilai Variabel Y dan hasilnya dicantumkan kepada kolom $\mathrm{Y}^{2}$ kemudian dijumlahkan

e. Mencari angka korelasi

Selanjutnya hasil perhitungan korelasi antara pengaruh program Booking service dalam meningkatkan kepuasan pelanggan dimasukkan kedalam rumus korelasi, yaitu:

$$
\begin{aligned}
& \mathrm{r} x y=\frac{\mathrm{n} \sum x y-\sum x \sum y}{\sqrt{\left\{\mathrm{n} \sum x^{2}-\left(\sum x\right)^{2}\right\}\left\{\mathrm{n} \sum y^{2}-\left(\sum y\right)^{2}\right\}}} \\
& =\frac{85(31263)-(1544)(1715)}{\sqrt{\left\{85(28520)-(1544)^{2}\right\}\left\{85(34968)-(1715)^{2}\right\}}} \\
& =\frac{2657355-2647960}{\sqrt{\{2424200-2383936\}\{2972280-2941225\}}}
\end{aligned}
$$

$$
\begin{aligned}
& \mathrm{r} x y=\frac{9395}{\sqrt{(40264)(31055)}} \\
& \mathrm{r} x y=\frac{\frac{9395}{\sqrt{1250398520}}}{\mathrm{r} x y=\frac{9395}{35360,974}}
\end{aligned}
$$

$\mathrm{r} x y=0,265$ (tiga angka dibelakang koma)

Jadi, Nilai Koefisien Korelasi $=0,265$

Nilai koefisien korelasi diatas dapat ditafsirkan dengan melihat tinggi rendahnya hubungan, dengan ketentuan sebagai berikut:

Tabel Tingkat Hubungan Nilai Koefisien Korelasi

\begin{tabular}{|r|l|l|}
\hline No. & $\begin{array}{l}\text { Besarnya } \\
\text { Nilai } \mathbf{~}\end{array}$ & $\begin{array}{l}\text { Tingkat Hubungan } \\
(\text { Interprestasi })\end{array}$ \\
\hline 1. & $0,000-0,199$ & Sangat rendah \\
\hline 2. & $\mathbf{0 , 2 0 0 - \mathbf { 0 , 3 9 9 }}$ & Rendah \\
\hline 3. & $0,400-0,599$ & Sedang \\
\hline 4. & $0,600-0,799$ & Kuat \\
\hline 5. & $0,800-1,000$ & Sangat kuat \\
\hline
\end{tabular}

Sumber: Buku Statistik Industri II

Maka nilai rxy yang di uji adalah $(0,265)$ berada pada kategori "Rendah". Dengan kata lain pengaruh anatar X (Program Booking service) dengan Y (Kepuasaan Pelanggan) adalah pengaruh yang Rendah. Makanya perlu dilakukan perbaikanperbaikan yang berkelanjutan / Perlu menerapkan Metode Kaizen sehingga Program Booking service ini mempunyai pengaruh yang kuat untuk meningkatkan kepuasan pelanggan.

Setelah diperoleh angka korelasi (r) sebesar 0,265. Kemudian untuk melakukan pengujian data terhadap angka korelasi maka akan dilakukan melalui uji signifikansi atau uji t deangan kriteria hipotesis sebagai berikut:

Ho = Tidak ada pengaruh Program Booking service terhadap kepuasan pelanggan

$\mathrm{Ha}=$ Ada pengaruh Program Booking service terhadap kepuasan pelanggan.

Selanjutnya dilakukan pengujian hipotesis dengan menggunkan uji t, untuk mengetahui signifikansi (nyata) tidaknya peranan $\mathrm{X}$ terhadap $\mathrm{Y}$, maka hasil pengujiannya adalah sebagai berikut:

$$
\begin{aligned}
& \text { thitung }=\frac{r \sqrt{n-2}}{\sqrt{1-r^{2}}} \\
& \text { thitung }=\frac{0,265 \sqrt{85-2}}{\sqrt{1-(0,265)^{2}}} \\
& \text { t hitung }=\frac{0,265 \sqrt{83}}{\sqrt{1-0,07}} \\
& \text { t hitung }=\frac{0,265(9,11)}{\sqrt{0,93}} \\
& t \text { hitung }=\frac{2,414}{0,964} \\
& \text { t hitung }=2,504
\end{aligned}
$$

Nilai thitung dibandingkan dengan nilai t tabel, untuk melihat nilai $\mathrm{t}$ tabel diguanakan dengan cara sebagai beriku:

Derajat kebebasan $(\mathrm{DK})=\mathrm{n}-2$

$$
\begin{aligned}
& =85-2 \\
& =83
\end{aligned}
$$

Taraf signifikan $=5 \%$

Uji dua pihak

t hitung $=2,504$

t tabel = 1,9889 (Dapat dilihat pada Lampiran-2)

Berdasarkan hasil perhitungan, maka t hitung $>\mathrm{t}$ tabel $(2,504>1,9889)$ maka dengan demikian $\mathrm{Ha}$ diterima, artinya Program Booking service (X) ternyata berperan terhadap Kepuasan Konsumen (Y) pada tingkat kepercayaan $5 \%$.

Hipotesis diterima :

Berarti ada pengaruh anatara Program Booking service (Variabel X) dengan Kepuasan konsumen (Variabel Y)

Diuji melalui perhitungan Determinasi (D) sebagai berikut :

$\mathrm{D}=\mathrm{rxy}^{2} \mathrm{x} 100 \%$

$\mathrm{D}=(0,265)^{2} \times 100 \%$

$\mathrm{D}=0,07022 \times 100 \%$

$\mathrm{D}=\mathbf{7 , 0 2 2 \%}$

Sisa $=100 \%-7,022 \%$

$$
\mathbf{= 9 2 , 9 7 8 \%}
$$

Dari nilai diatas dapat dilihat bahwa variabel $\mathrm{X}$ (Program Booking service) terhadap Varibel Y (Kepuasan Konsumen) sebesar 7,022\% dan sisanya 92,978\% efektifitas kerja dipengaruhi variabel lain diluar penelitian ini. Maka perlu dilakukan perbaikan secara terus-menerus untuk meningkatkan pengaruh Program Booking service terhadap kepuasan pelanggan. 


\section{ANALISA DAN EVALUASI}

\section{Analisa}

Berdasarkan perhitungan yang dilakukan, data menunjukkan bahwa semua pertanyaan valid, ini terbukti bahwa hubungan antara Program Booking Service terhadap Kepuasan Pelanggan ternyata "Rendah". Hal ini dibuktikan dengan Korelasi $\mathrm{r}=$ 0,265 .

Untuk mengetahui signifikan tidaknya pengaruh Booking Service terhadap kepuasan konsumen, maka diperoleh uji signifikan yakni uji-t, setelah dilakuakan uji dua pihak ternyata terbukti bahwa thitung lebih besar dari t-tabel $(2,504>1,9889)$ maka Ha diterima, artinya Program Booking Service (Variabel X) berpengaruh terhadap Kepuasan Konsumen (Variabel Y) walaupun masih memiliki pengaruh yang rendah.

Sebab kekuatan pengaruh Program Booking Service berpengaruh terhadap Kepuasan Konsumen dapat diukur dengan koefisien determinasi yaitu sebesar $7,022 \%$ dan sisanya $92,978 \%$ efektifitas kerja dipengaruhi variabel lain diluar penelitian ini. Maka perlu dilakukan perbaikan secara terus-menerus untuk meningkatkan pengaruh Program Booking service terhadap kepuasan Konsumen.

\section{Evaluasi}

Setelah menganalisa pengolahan data yang diperoleh Auto 2000 SM Raja Medan, maka diketahui pengaruh Program Booking Service terhadap kepuasan Konsumen masih Rendah, maka perlu ditingkatkan dengan mengevaluasi data KPI Kaizen Auto 2000 SM Raja Medan, dengan melakukan perbaikan secara terus menerus atau menerapkan Metode Kaizen.

Konsep Metode Kaizen yang digunakan adalah: Konsep PDCA (Plan, Do, Check, Action). Langkah pertama dari kaizen adalah menerapkan siklus PDCA (plan, do, check action) sebagian sarana yang menjamin terlaksananya kesinambungan dari kaizen. Hal ini berguna dalam mewujudkan kebijakan untuk memelihara dan memperbaiki atau meningkatkan standar.

Dari data yang diperoleh bahwa masalah yang paling banyak dikeluhkan pelanggan adalah Masalah Waktu Tunggu. Masalah yang paling dikeluhkan pelanggan adalah Waktu Tunggu Telepon Pelanggan yang susah masuk jika ditelepon ke bagian Booking Service untuk melakukan registrasi Booking Service sehingga hal tersebut menjadi kendala dalam melakukan Booking Service diakibatkan banyaknya telepon yang menunggu. Sehingga dapat mengurangi kepuasan pelanggan dalam pelayanan Booking Service. Maka untuk mengatasi masalah tersebut adalah menerapkan konsep PDCA.
Konsep PDCA yang pada hakekatnya merupakan siklus, maka pada implementasinya akan membangun budaya mutu yang continual improvement. Implementasi konsep PDCA untuk manajemen mutu hal kepuasan pelanggan akan dijabarkan berikut ini:

\section{Plan (perencanaan)}

Yaitu apa yang harus dilakukan dan bagaimana melakukannya? Pada tahapan perencanaan ini, rumusan desain kepuasaan pelanggannya diarahkan pada mengembangkan sasaran dan proses-proses yang diperlukan untuk mencapai hasil yang sesuai dengan kebijakan perusahaan atau sesuai persyaratan pengguna.

Untuk mengatasi waktu tunggu telepon pelanggan adalah:

a. Menambah jumlah operator dibagian Booking Service.

Jumlah pegawai dalam bidang Booking Service saat ini adalah ada 4 orang. Yaitu 2 orang pada bagian pendaftaran Booking Service dan 2 orang pada bagian MRS sementara jumlah pelanggan adalah ribuan jadi jumlah anatara pelanggan dan operator tidak seimbang. Jadi dengan penambahan jumlah operator maka jumlah telepon semakin banyak sebagai akses oleh pelanggan untuk melakukan Booking Service sehingga waktu tunggu telepon akan berkurang.

b. Menambah Akses dengan Via Whatsapp dan Aplikasi Line

Selama ini via akses untuk melakukan Booking Service hanya:

- Telephone : 061-7354888

- SMS :0812-6325-2000

- BBM :2B3D07B5

- E-Mail :

Booking.medanssm@tso.astra.co.id

Jadi perlu ditambah akses agar lebih banyak sehingga lebih mudah untuk melakukan Booking Service, seperti Whatsapp dan Aplikasi Line misalnya apalagi sekarang smartphone lagi marakmaraknya dikalangan masyarakat menengah ke atas jadi aplikasi ini sangat mendukung komunikasi supaya lebih lancar.

WhatsApp dan Aplikasi Line adalah aplikasi pesan untuk smartphone. WhatsApp Messenger dan Aplikasi Line merupakan aplikasi pesan lintas platform yang memungkinkan kita bertukar pesan tanpa biaya SMS, karena WhatsApp Messenger dan Aplikasi Line menggunakan paket data internet yang sama untuk email, browsing web, dan lain-lain. Aplikasi WhatsApp Messenger dan Aplikasi Line menggunakan koneksi $3 \mathrm{G}$ atau WiFi untuk komunikasi data. Dengan menggunakan WhatsApp, kita dapat melakukan obrolan online, berbagi file, bertukar foto dan lain-lain. Cuma bedanya WhatsApp menggunakan nomor telepon sebagai Pin. Sedangkan Aplikasi Line menggunakan ID 
Sebab beberapa keuntungan memakai WhatsApp dan Aplikasi Line adalah sebagai berikut:

1. Tidak hanya teks: WhatsApp dan Aplikasi Line memiliki fitur untuk mengirim gambar, video, suara, dan lokasi GPS via hardware GPS atau Gmaps. Media tersebut langsung dapat ditampilkan dan bukan berupa link.

2. Terintegrasi ke dalam sistem : WhatsApp dan Aplikasi Line, layaknya sms, tidak perlu membuka aplikasi untuk menerima sebuah pesan. Notifikasi pesan masuk ketika handphone sedang off akan tetap disampaikan jika handphone sudah $o n$.

3. Status Pesan :

- Jam Merah untuk proses loading di HP kita

- Tanda Centang jika pesan terkirim ke jaringan

- Tanda centang ganda jika pesan sudah terkirim ke teman chat.

- Silang merah jika pesan gagal

- Kalau untuk Aplikasi Line, pengguna bisa mengetahui status pesan apakah sudah tterkirim atau tidak, sebab akan muncul kata "Read" pada pesan yang kita kirim apabila sudah dibaca oleh penerima pesan.

4. Broadcats dan Group chat : Broadcast untuk kirim pesan ke banyak pengguna. Group chat untuk mengirim pesan ke anggota sesama komunitas/pelanggan Booking Service.

5. Hemat Bandwidth : Karena terintegrasi dengan sistem, maka tidak perlu login dan loading contact/avatar, sehingga transaksi data makin irit. Aplikasi dapat dimatikan, dan hanya aktif jika ada pesan masuk, sehingga bisa menghemat batrei.

Jadi dari kelebihan-kebihan tersebut makanya komunikasi akan semakin mudah lancer sehingga gangguan untuk melakukan Booking Service akan teratasi.

\section{Do (melaksanakan)}

yaitu mengerjakan yang direncanakan. Pada tahapan melaksanakan ini, rumusan desain kepuasan pelanggannya diarahkan pada melaksanakan strategi, kebijakan, dan prosesproses yang diperlukan untuk mencapai hasil yang telah ditetapkan dalam sasaran mutu atau sesuai persyaratan pengguna.

Dalam konsep ini yang dilakukan adalah :

a. Menambah Akses dengan Via Whatsapp dan Line

b. Menambah jumlah operator dibagian Booking Service.

Didalamnya berisi pelatihan dan manajemen aktivitas. Biasanya masalah besar dan mudah sering berubah pada saat-saat terakhir. Bila terjadi kondisi seperti ini maka tidak dapat dilanjutkan lagi tetapi harus mulai dari awal kembali.

a. Merencanakan suatu proyek uji coba

- Merencanakan sumber daya manusia, sumber dana, dan sebagainya.

- Merencanakan rencana kegiatan (plan of action)

b. Melaksanakan Pilot Project

Pilot Project dilaksanakan dalam skala kecil

dengan waktu relatif singkat ( \pm 2 minggu).

\section{Check (meriksa)}

Yaitu apakah hasil yang terjadi sesuai dengan yang direncanakan. Pada tahapan memeriksa ini, kepuasan pelanggannya diarahkan pada memantau, mengevaluasi, mengukur kesesuaian proses-proses yang telah dijalankan dan yang telah dihasilkan dengan kebijakan perusahaan, sasaran mutu dan persyaratan yang telah ditetapkan. diperlukan untuk mencapai hasil yang sesuai dengan kebijakan perusahaan atau sesuai persyaratan pengguna.

Dalam konsep ini dilakukan pemeriksaan apakah program yang dijalankan sesuai dengan rencana. Berarti pengecekan terhadap hasil dan membandingkan sesuai dengan yang diinginkan. Bila segala sesuatu menjadi buruk dan hasil baik tidak ditemukan, pada bagian ini keberanian, kejujuran, kecerdasan sangat dibutuhkan untuk mengendalikan proses. Kata kunci ketika hasil memburuk adalah "kenapa". Dengan dokumentasi proses yang baik maka kita dapat kembali pada titik yang mana keputusan yang salah dibuat.

a. Evaluasi hasil program

- Bertujuan untuk efektivitas program tersebut

- Membandingkan target dengan hasil pencapaian program (data yang dikumpulkan dan teknik pengumpulan data harus sama)

- Target yang ingin dicapai

- Teknik yang digunakan: observasi dan survei

- Alat yang digunakan: kuisioner

b. Membuat kesimpulan program

- Hasil menjanjikan namun perlu perubahan

- Jika program gagal, cari penyelesaian lain Jika program berhasil, selanjutnya dibuat rutinitas

\section{Action (tindak lanjut)}

Yaitu apakah tindak lanjut yang akan diambil dengan hasil yang diperoleh dan upaya yang diperlukan untuk meningkatkan hasil yang diperoleh?

Berarti Menindak lanjuti atas apa yang didapatkan selama tahap pengecekan. Arti lainnya adalah mencapai tujuan dan menstandarisasikan 
proses atau belajar dari pengalaman untuk memulai lagi pada kondisi yang tepat.

a. Standarisasi perubahan

- Pertimbangkan area mana saja yang mungkin diterapkan

- Revisi proses yang sudah diperbaiki

- Modifikasi standar, prosedur dan kebijakan yang ada

- Komunikasikan kepada seluruh staf, pelanggan dan suplier atas perubahan yang dilakukan.

- Lakukan pelatihan bila perlu

- Mengembangkan rencana yang jelas

- Dokumentasikan proyek

b. Memonitor perubahan

- Melakukan pengukuran dan pengendalian proses secara teratur.

Disamping melakukan peningkatan terhadap pengaruh Booking Service terhadap kepuasan konsumen maka perlu dilakukan sosialisasi supaya konsumen mengetahui keuntungan dari melakukan Booking Service, sebab dengan melakukan Booking Service maka pelanggan akan mendapatkan beberapa keuntungan sebagai berikut:

- Terencana. Waktu ke bengkel,pemilik mobil atau pelanggan servis dapat menentukan sendiri waktu servis buat kenderaannya

- Tidak perlu antri. Pemilik kenderaan yang telah melakukan Booking Service akan langsung dilayani

- Lebih cepat selesai. Mobil pelanggan servis lebih cepat selesai karena sudah terencana dan terhindar dari antrian

- Part dan mekanik siap. Tools dan spare part untuk mobil yang Booking Service telah tersedia sesuai kebutuhan

- Lebih hemat. Pemilik yang Booking Service akan mendapatkan diskon $15 \%$ untu jasa dan spare part $3 \%$ (khusus untuk servis berkala). Free jasa sampai dengan 50.000 $\mathrm{km} / 4$ tahun (syarat dan ketentuan berlaku).

Dengan mengetahui keuntungan dari Booking Service semoga para konsumen lebih banyak melakukan Booking Service untuk menyervis kenderaannya.

Selain itu di PT. Astra International Tbk, pada setiap hari Kamis para operator di bidang Booking Service melakukan Meeting evaluasi untuk mengevaluasi program yang dijalankan perminggunya apakah sudah sesuai dengan rencana, dan terus melakukan perbaikan secara-terus menerus sehingga Visi ingin menjadi Dealer Car terbaik di Indonesia akan tercapai.

\section{KESIMPULAN DAN SARAN}

\section{Kesimpulan}

Setelah dilakukan analisis terhadap pengaruh Program Booking Service terhadap kepuasan konsumen dengan menggunakan Metode Analisis Korelasi dan menerapkan Metode Kaizen maka Peneliti menyimpulkan bahwa hubungan antara Program Booking Service terhadap Kepuasan konsumen ternyata "Rendah". Hal ini dibuktikan dengan Korelasi $r=0,265$. Sebab berdasarkan Tabel Nilai Hubungan Koefisien Korelasi apabila r berada diantara 0,200 - 0.399 ditafsirkan hubungan antara variabel adalah masih Rendah. Kekuatan pengaruh Program Booking Service berpengaruh terhadap Kepuasan konsumen dapat diukur dengan koefisien determinasi yaitu sebesar 7,022\% dan sisanya $92,978 \%$ efektifitas kerja dipengaruhi variabel lain diluar penelitian ini. Perlu dilakukan perbaikan untuk meningkatkan pengaruh Program Booking service terhadap kepuasan konsumen.

\section{Saran}

Dari hasil evaluasi serta perhitungan korelasi yang diteliti pengaruh Program Booking Service terhadap kepuasan konsumen masih "Rendah". Maka seharusnya perusahaan melakukan perbaikan dalam hal meminimalisasi waktu tunggu telepon konsumen, dan meningkatkan pelayanan Program Booking service kepada konsumen dengan cara:

a. Menambah Akses dengan Via Whatsapp dan Aplikasi Line

b. Menambah jumlah operator dibagian Booking Service.

c. Mengingat pengaruh yang kurang signifikan, perlu di tambah bentuk pelayanan lain seperti Toyota Home Service (THS) untuk meningkatkan kepuasaan konsumen. Dimana program-program tersebut diterapkan dengan metode Kaizen.

\section{DAFTAR PUSTAKA}

Candra, Gregorius; (2002) "Prosedur Penelitian Suatu Pendekatan Praktek”. Rineka Cipta.Jakarta.

Hasibuan, Abdurrozzaq; (2013) "Metodologi Penelitian”. LPPM UISU. Medan.

Kotler, Philip; (2002) "Manajemen Pemasaran di Indonesia : Analisis, Perencanaan, Implementas dan Pengendalian”. Salemba Empat. Jakarta.

Moenir,H.A.S; (1998) "Manajemen Pelayanan Umum di Indonesia”. Edisi Pertama, Cetakan Pertama, Bumi Aksara. Jakarta.

Razi Fakhrur, Nurmansyah; (2008) “Analisa Pengaruh Layanan Pengantaran Produk Terhadap Kepuasan Konsumen 
Pada PT.Daya Prima Indonesia”.

Tugas Akhir Teknik Industri UISU. Medan.

Tjiptono, Fandy ; (2001) “Strategi Pemasaran”. Edisi Pertama. Andi Ofset. Yogyakarta. http://www.astra.co.id/m

http://id.m.wikipedian.org/wiki/kaizen

http://www.academia.edu/4410488/kaizen_dan_impl ementasinya

\section{LAMPIRAN}

Lampiran-1 Perhitungan Korelasi antara Variabel X dan Variabel Y

\begin{tabular}{|c|c|c|c|c|c|}
\hline subyek & $\mathbf{x}$ & $\mathbf{y}$ & $x y$ & $\mathbf{X}^{2}$ & $\mathbf{y}^{2}$ \\
\hline 1 & 15 & 21 & 315 & 225 & 441 \\
\hline 2 & 17 & 21 & 357 & 289 & 441 \\
\hline 3 & 20 & 23 & 460 & 400 & 529 \\
\hline 4 & 20 & 22 & 440 & 400 & 484 \\
\hline 5 & 17 & 21 & 357 & 289 & 441 \\
\hline 6 & 18 & 21 & 378 & 324 & 441 \\
\hline 7 & 17 & 21 & 357 & 289 & 441 \\
\hline 8 & 19 & 21 & 399 & 361 & 441 \\
\hline 9 & 15 & 21 & 315 & 225 & 441 \\
\hline 10 & 20 & 18 & 360 & 400 & 324 \\
\hline 11 & 17 & 19 & 323 & 289 & 361 \\
\hline 12 & 16 & 23 & 368 & 256 & 529 \\
\hline 13 & 21 & 21 & 441 & 441 & 441 \\
\hline 14 & 18 & 21 & 378 & 324 & 441 \\
\hline 15 & 19 & 21 & 399 & 361 & 441 \\
\hline 16 & 18 & 20 & 360 & 324 & 400 \\
\hline 17 & 21 & 24 & 504 & 441 & 576 \\
\hline 18 & 18 & 23 & 414 & 324 & 529 \\
\hline 19 & 19 & 22 & 418 & 361 & 484 \\
\hline 20 & 18 & 21 & 378 & 324 & 441 \\
\hline 21 & 20 & 21 & 420 & 400 & 441 \\
\hline 22 & 19 & 22 & 418 & 361 & 484 \\
\hline 23 & 20 & 21 & 420 & 400 & 441 \\
\hline 24 & 19 & 20 & 380 & 361 & 400 \\
\hline 25 & 19 & 22 & 418 & 361 & 484 \\
\hline 26 & 19 & 21 & 399 & 361 & 441 \\
\hline 27 & 15 & 20 & 300 & 225 & 400 \\
\hline 28 & 19 & 21 & 399 & 361 & 441 \\
\hline 29 & 19 & 21 & 399 & 361 & 441 \\
\hline 30 & 16 & 19 & 304 & 256 & 361 \\
\hline 31 & 16 & 21 & 336 & 256 & 441 \\
\hline 32 & 20 & 22 & 440 & 400 & 484 \\
\hline 33 & 14 & 16 & 224 & 196 & 256 \\
\hline 34 & 15 & 17 & 255 & 225 & 289 \\
\hline 35 & 16 & 15 & 240 & 256 & 225 \\
\hline 36 & 15 & 16 & 240 & 225 & 256 \\
\hline
\end{tabular}




\begin{tabular}{|c|c|c|c|c|c|}
\hline 37 & 19 & 22 & 418 & 361 & 484 \\
\hline 38 & 18 & 20 & 360 & 324 & 400 \\
\hline 39 & 19 & 20 & 380 & 361 & 400 \\
\hline 40 & 17 & 20 & 340 & 289 & 400 \\
\hline 41 & 13 & 17 & 221 & 169 & 289 \\
\hline 42 & 15 & 17 & 255 & 225 & 361 \\
\hline 43 & 11 & 15 & 165 & 121 & 225 \\
\hline 44 & 19 & 23 & 437 & 361 & 529 \\
\hline 45 & 18 & 24 & 432 & 324 & 324 \\
\hline 46 & 21 & 17 & 357 & 441 & 289 \\
\hline 47 & 20 & 17 & 340 & 400 & 289 \\
\hline 48 & 18 & 23 & 414 & 324 & 529 \\
\hline 49 & 15 & 22 & 330 & 225 & 484 \\
\hline 50 & 18 & 23 & 414 & 324 & 529 \\
\hline 51 & 18 & 23 & 414 & 324 & 529 \\
\hline 52 & 18 & 20 & 360 & 324 & 400 \\
\hline 53 & 20 & 19 & 380 & 400 & 361 \\
\hline 54 & 19 & 17 & 323 & 361 & 289 \\
\hline 55 & 20 & 21 & 420 & 484 & 324 \\
\hline 56 & 20 & 18 & 360 & 400 & 324 \\
\hline 57 & 17 & 22 & 374 & 289 & 484 \\
\hline 58 & 20 & 22 & 440 & 400 & 484 \\
\hline 59 & 20 & 21 & 420 & 400 & 441 \\
\hline 60 & 19 & 22 & 418 & 361 & 484 \\
\hline 61 & 20 & 24 & 480 & 400 & 576 \\
\hline 62 & 18 & 22 & 396 & 324 & 484 \\
\hline 63 & 17 & 23 & 391 & 289 & 529 \\
\hline 64 & 19 & 20 & 380 & 361 & 400 \\
\hline 65 & 20 & 23 & 460 & 400 & 529 \\
\hline 66 & 19 & 22 & 418 & 361 & 484 \\
\hline 67 & 19 & 20 & 380 & 361 & 400 \\
\hline 68 & 18 & 23 & 414 & 324 & 529 \\
\hline 69 & 20 & 22 & 440 & 400 & 484 \\
\hline 70 & 18 & 20 & 360 & 324 & 400 \\
\hline 71 & 22 & 18 & 396 & 484 & 324 \\
\hline 72 & 21 & 18 & 378 & 441 & 324 \\
\hline 73 & 19 & 17 & 323 & 361 & 289 \\
\hline 74 & 20 & 17 & 340 & 400 & 289 \\
\hline 75 & 20 & 17 & 340 & 400 & 289 \\
\hline 76 & 18 & 18 & 324 & 324 & 324 \\
\hline 77 & 15 & 19 & 285 & 225 & 361 \\
\hline 78 & 14 & 17 & 238 & 196 & 289 \\
\hline 79 & 13 & 19 & 247 & 169 & 361 \\
\hline 80 & 17 & 16 & 272 & 289 & 256 \\
\hline
\end{tabular}




\begin{tabular}{|c|c|c|c|c|c|}
81 & 20 & 20 & 400 & 400 & 400 \\
\hline 82 & 21 & 19 & 399 & 441 & 441 \\
\hline 83 & 21 & 18 & 378 & 441 & 441 \\
\hline 84 & 20 & 17 & 340 & 400 & 400 \\
\hline 85 & 19 & 21 & 399 & 361 & 361 \\
\hline & 1544 & 1715 & 31263 & 28520 & 34968 \\
\hline
\end{tabular}

\section{Lampiran-2 Tabel Distribusi t}

\begin{tabular}{|c|c|c|c|c|c|c|c|}
\hline DK & $\mathbf{0 , 2 5}$ & $\mathbf{0 , 1}$ & $\mathbf{0 , 0 5}$ & $\mathbf{0 , 0 2 5}$ & $\mathbf{0 , 0 2}$ & $\mathbf{0 , 0 1}$ & $\mathbf{0 , 0 0 5}$ \\
\hline 1 & 2,4142 & 6,3138 & 12,706 & 25,452 & 31,821 & 63,657 & 127,32 \\
\hline 2 & 1,6036 & 2,92 & 4,3027 & 6,2053 & 6,965 & 9,9248 & 14,089 \\
\hline 3 & 1,4226 & 2,3534 & 3,1825 & 4,1765 & 4,541 & 5,8409 & 7,4533 \\
\hline 4 & 1,3444 & 2,1318 & 2,7764 & 3,4954 & 3,747 & 4,6041 & 5,5976 \\
\hline 5 & 1,3009 & 2,015 & 2,5706 & 3,1634 & 3,365 & 4,0321 & 4,7733 \\
\hline 6 & 1,2733 & 1,9432 & 2,4469 & 2,9687 & 3,143 & 3,7074 & 4,3168 \\
\hline 7 & 1,2543 & 1,8946 & 2,3646 & 2,8412 & 2,998 & 3,4995 & 4,0293 \\
\hline 8 & 1,2403 & 1,8595 & 2,306 & 2,7515 & 2,896 & 3,3554 & 3,8325 \\
\hline 9 & 1,2297 & 1,8331 & 2,2622 & 2,685 & 2,821 & 3,2498 & 3,5814 \\
\hline 10 & 1,2213 & 1,8125 & 2,2281 & 2,6338 & 2,764 & 3,1693 & 3,5814 \\
\hline 1 & 1,2145 & 1,7959 & 2,201 & 2,5931 & 2,718 & 3,1058 & 3,4966 \\
\hline 12 & 1,2089 & 1,7823 & 2,1788 & 2,56 & 2,681 & 3,0545 & 3,4284 \\
\hline 13 & 1,2041 & 1,7709 & 2,1604 & 2,5326 & 2,65 & 3,0123 & 3,3725 \\
\hline 14 & 1,2001 & 1,7613 & 2,1448 & 2,5096 & 2,624 & 2,9768 & 3,3257 \\
\hline 15 & 1,1967 & 1,753 & 2,1315 & 2,4899 & 2,602 & 2,9467 & 3,286 \\
\hline 16 & 1,1937 & 1,7459 & 2,1199 & 2,4729 & 2,583 & 2,9208 & 3,252 \\
\hline 17 & 1,191 & 1,7396 & 2,1098 & 2,4581 & 2,567 & 2,8982 & 3,2225 \\
\hline 18 & 1,1887 & 1,7341 & 2,1009 & 2,445 & 2,552 & 2,8784 & 3,1966 \\
\hline 19 & 1,1866 & 1,7291 & 2,093 & 2,4334 & 2,593 & 2,8609 & 3,1737 \\
\hline 20 & 1,1848 & 1,7247 & 2,086 & 2,4231 & 2,528 & 2,8453 & 3,1534 \\
\hline 21 & 1,1831 & 1,7207 & 2,0796 & 2,4138 & 2,518 & 2,8314 & 3,1352 \\
\hline 22 & 1,1816 & 1,7171 & 2,0739 & 2,4055 & 2,508 & 2,8188 & 3,1188 \\
\hline 23 & 1,1802 & 1,7139 & 2,0639 & 2,391 & 2,492 & 2,8073 & 3,104 \\
\hline 24 & 1,1789 & 1,7109 & 2,0639 & 2,391 & 2,492 & 2,7969 & 3,0905 \\
\hline 25 & 1,1777 & 1,7081 & 2,0595 & 2,3846 & 2,485 & 2,7874 & 3,0782 \\
\hline 26 & 1,1766 & 1,7056 & 2,0555 & 2,3788 & 2,479 & 2,7787 & 3,0669 \\
\hline 27 & 1,1757 & 1,7033 & 2,0518 & 2,3734 & 2,473 & 2,7707 & 3,0565 \\
\hline
\end{tabular}

C-173 


\begin{tabular}{|c|c|c|c|c|c|c|c|}
28 & 1,1748 & 1,7011 & 2,0484 & 2,3685 & 2,467 & 2,7633 & 3,0469 \\
\hline 29 & 1,1739 & 1,6991 & 2,0452 & 2,3638 & 2,462 & 2,7564 & 3,038 \\
\hline 30 & 1,1731 & 1,6973 & 2,0423 & 2,3596 & 2,457 & 2,75 & 3,0298 \\
\hline 40 & 1,1673 & 1,6839 & 2,0211 & 2,3289 & 2,423 & 2,7045 & 2,9712 \\
\hline $\mathbf{8 3}$ & 0,6774 & 1,6634 & $\mathbf{1 , 9 8 8 9}$ & 2,0677 & 2,3721 & 2,6363 & 2,8890 \\
\hline
\end{tabular}

